\title{
The Leading Indicators of the Economic Cycles in Lithuania
}

\author{
Alina Stundziene, Vytautas Barkauskas, Vilda Giziene
}

\author{
Kaunas University of Technology \\ K. Donelaicio st. 73, LT-44029, Kaunas, Lithuania \\ E-mail.alina.stundziene@ktu.lt,vytautas.barkauskas@ktu.lt,vilda.giziene@ktu.lt
}

cross $^{\text {ref }}$ http://dx.doi.org/10.5755/j01.ee.28.3.16705

\begin{abstract}
The identification of the leading indicators that precede economic events and predict the next phase of the economic cycle is undoubtedly an important issue seeking to protect a country against recession or other negative economic events. The literature analysis shows that leading indicators vary across the countries and time. Therefore the aim of this research is to analyse potential leading indicators and identify the best predictors of the economic cycles in Lithuania. Various economic, industrial, financial, real estate market indicators as well as consumer and business expectations are analysed in order to find out which indicators cause the changes in the growth rate of GDP. The analysis is based on Granger causality test and autoregressive distributed lag model. The research shows that economic indicators such as consumption expenditure of households, government debt, compensation of employees, unemployment and others are weak predictors of the growth rate of GDP. Volume index of intermediate goods production is the best predictor in the group of industry data as it holds predictive attributes even three years before the changes in economy. The same conclusion can be made considering two financial indicators, i.e. short-term interest rate and the value of stock market index. Real estate market data such as residential buildings permits and growth rate in house price index can also warn about the changes in the growth rate of GDP two years before. Nevertheless, consumer and business expectations are the most important for the prediction of the changes in the growth rate of GDP.
\end{abstract}

Keywords: Leading Indicators, Economic Cycles, Prediction, GDP, Lithuania.

\section{Introduction}

The economy of the state is described by various indicators. They are always in the centre of attention of governments, businessmen and economists. The changes in economy touch every person of the population. One plans his/her finance, career perspectives and business according to the projections of the economic indicators. Various economic indicators are released by government agencies, non-profit organizations and even private companies monthly, quarterly and annually. They provide the information about the economic situation of the country, the latest economic cycles, consumer spending, business expectations and so on. Economic cycles may be defined as broad-based recurrent medium-term fluctuations in economic activity (ECB, 2001). Nevertheless it must be taken into account that nothing is stable. Economists constantly monitor and analyse the changes in the economy and provide their insights to community. However, analysts' opinions often differ and some of their predictions are incorrect. Despite of its great importance, prediction of economic cycles is still a tough task with limited success in economic analysis.

The identification of the indicators that signal about the changes in the economy is one of the crucial points in the prediction of the economic (or business) cycles. These indicators are known as leading indicators that precede economic events and predict the next phase of the business cycle. That becomes critical when the economy is either going to a recession or coming out of it. Governments and policymakers make use of the leading indicators when they want to implement or alter the programs in order to protect the country against the recession or other negative economic events.

The identification of the leading indicators is under investigation by lots of researchers all over the world, but the problem is that studies are mainly oriented to the largest countries of the world. Moreover, the literature analysis shows that leading indicators vary across the countries and time. Researchers employ various methods in order to predict the economic indicators and the business cycles. Despite that, still consensus on common framework of the analysis of the economic cycles is not reached and none of the existing models are reliable. Many models utilize quarterly or even annual data and are not well suited for the analysis of quickly changing conditions (Megna \& Xu, 2003).

The aim of this research is to identify the leading indicators of the economic cycles in Lithuania. The potential leading indicators were selected based on the literature analysis. The identification of the leading indicators is essential for the government to pass the laws, for businessmen to plan their future activity and each inhabitant to plan their finance.

\section{Literature Analysis}

Information about future changes in economy is helpful for various economic agents. If policymakers learned more about future economic conditions, they could better adopt policies. If businessmen were able to predict the future, they could better plan business projects. Scientists have long examined predictive ability of various economic indicators for future business cycles, but still consensus on this question is not reached (Nakaota \& Fukuta, 2013). 
The economy of the state is usually described by the group of the indicators that can be characterized as lowfrequency data as they are observed and published monthly, quarterly or annually. But it is clear that such information is presented too late, i.e. the participants of the market must react quickly in order to be successful. The market participants face with rich macroeconomic news flow almost every day. This news flow contains the information that market participants use to learn about the economy before the official statistical information is published. Such flow is very useful as it is early information about the trends of various economic indicators and their changes. Researchers also try to avail this information and look for the methods to employ it for the prediction of the economic indicators. This is commonly referred to as "now-casting" that has been analysed by Koenig et al. (2003), Banbura et al. (2013), Beber et al. (2015) and others.

Koenig et al. (2003) forecasted real GDP growth for a quarter using monthly data on employment, industrial production, and retail sales, but acknowledged that the forecasts were not very accurate. Beber et al. (2015) research, based on the US data, showed that an economic activity and macroeconomic sentiment factor had sensible dynamics. The macroeconomic sentiment factor (or business and consumer confidence) was highly correlated with the economic activity, but appeared to lead the fundamentals around significant turning points. Meanwhile inflation weakly correlated with growth and had an unclear pattern in expansions.

In general, cyclical indicators are classified into three categories based on the timing of their movements, i.e. leading, coincident and lagging. Coincident indicators estimate aggregate economic activity and determine the business cycle. Business and consumer surveys data are coincident or leading indicators as they provide information regarding the assessment of economic agents of the current economic situation and their expectations for the future. Production, employment, personal income, trade sales and manufacturing are often called as coincident indicators. Meanwhile such indicators as new orders, average weekly hours, housing permits, consumer expectations, stock prices and the interest rate spread are leading indicators, as they change the direction of movement in advance of the economic cycle. Nevertheless, leading indicators are more meaningful when they are used together with coincident and lagging indicators. Contrary to the leading indicators, the lagging indicators change the direction later than coincident indicators (Conference Board, 2001).

The literature has used three approaches to determine the potential leading indicators. First, variables are chosen based on the theoretical studies. Usually few potential indicators are analysed, but sometimes various transformations of these indicators are also included. Second, studies are often based on systematic literature reviews. They analyse previously published research, choose useful leading indicators from there and sometimes include some other indicators and their transformations (Frankel \& Saravelos, 2012; Rose \& Spiegel, 2011). Third, researchers take all indicators that are available in a selected database. None approach is protected against omission of important potential indicators (Babecky et al., 2013).
As a starting point for the choice of useful leading indicators for the EU and the OECD countries, Babecky et al. (2013) identified more than one hundred relevant financial and macroeconomic indicators based on the studies of other researchers such as Alessi and Detken (2011), Rose and Spiegel (2011), Frankel and Saravelos (2012) and constructed the index of real costs which was obtained as an average of standardized GDP growth, standardized unemployment rate, and standardized government budget deficit. According to Babecky et al. (2013) their results were more optimistic than those of Rose and Spiegel (2011) who investigated which of the leading indicators were effective in explaining the crisis in 2000. In comparison to Frankel and Saravelos (2012), who presented that the real appreciation and level of reserves were useful leading indicators, Babecky et al. (2013) found other indicators more informative. They stated that about a third of the potential leading indicators were informative for explaining the incidence of the economic crises in the OECD and the EU countries in the past 40 years. Babecky et al. (2013) suggest that share prices, domestic housing prices, credit growth, private credit and some other variables are the most useful leading indicators and the growth in domestic credit signals about the changes even 4 years before while other research usually analyses only 1-2 years. Meanwhile, FDI inflow, the current account deficit, an increase in government debt, a drop in share prices and house prices betray a warning signal 5 or 6 quarters ahead and can be called as late leading indicators. Even late leading indicators may be useful for the identification of the crisis (Babecky et al., 2013).

Azevedo and Pereira (2013) presented a method designed for prediction of two measures of economic activity in real-time: the business cycle fluctuations of aggregate output and the smooth growth of real GDP. They illustrated the methodology and provided forecasts for the US and Portugal. The researchers highlighted that analysis of smoothed time series may be more useful than working with original series that are sometimes erratic and unpredictable, especially at long horizons.

Previous studies show that yield spread, which is defined as the difference between the long interest and the short interest rate, is an important predictor for future output (or growth rates of GDP) and recessions. Increasing yield spread is the leading indicator for expansions and decreasing yield spread is the leading indicator for recessions. Investors buy long term bonds and sell short term bonds when they expect recession, and, as the result, yield spread is decreasing (Christiansen, 2013). Nakaota and Fukuta (2013) add that positive correlation between the current yield spread and the future economic activity exist. If the current yield spread expands, the future economic conditions tend to improve, and vice versa.

There is a growing amount of literature on the relationship between the real economy and the financial markets. The importance of understanding these links better arose from the 2008-2009 global recession (Levanon et al., 2015). Banking system is an important part of market infrastructure. Decisions of banks affect the real sector and the changes in the real sector have influence on the whole banking system. The results of the study of Larionova and Varlamova (2014), where 17 OECD countries were under 
investigation, show that the indicators of the banking system mostly correlate with the income and spending of the households, as well as trade balance.

The research of Beber et al. (2015) showed that macroeconomic indicators correlated with the financial indicators, such as the implied stock return volatility index and the default spread. The relationship between the macroeconomic and financial indicators was also approved by some other researchers. Caldara et al. (2016) showed that financial shocks had negative impact on economic situation and were the reason of cyclical fluctuations in the US since 1980 .

Stock prices can also be the potential leading indicators as they reflect the expectations of the market participants about the future state of the economy. Rua and Nunes (2005) analysed European stock market indices for various economic sectors and concluded that stock market fluctuations were pro-cyclical and leading at medium cycles. However, they weakly correlated with the economic cycle if long or short time period was considered.

Levanon et al. (2015) evaluated the ability of the financial indicators to predict recessions in the US. They selected six financial indicators and aggregated them into a single composite index, which was named the Leading Credit Index (LCI). It aggregated different qualitative and quantitative survey indicators, which were related to the cost and availability of credit, and willingness of the economic agents to lend or borrow. They showed that leading credit index, either alone or as a component of the leading economic indicator (LEI), could be useful in estimating the probability of recession and it was better than the individual indicators.

The LEI aggregates ten components and is calculated similar to CEI composite index, which consist of index of industrial production, nonfarm payroll employment, manufacturing trade and sales, and personal income less transfer payments. These four components are also used by the National Bureau of Economic Research (NBER) for determination of the beginning and the end of the recessions in the US economy (Levanon et al., 2015; Conference Board, 2001).

Not only financial, but also uncertainty shocks have had the influence on the economic fluctuations over the past 40 years. Uncertainty shocks have greater impact when financial conditions are tightened (Caldara et al., 2016). Beber and others (2015) notice that opinions of economists significantly differ about the time of recovery, but they seems to agree about the end of an economic expansion.

In principle, a range of indicators can be taken into account when identifying the economic cycle, for example employment, income, trade or output. However, composite indicators are usually created based on the real GDP or the volume of industrial production. The advantage of industrial production is the availability of monthly data, however, it accounts for only about a quarter of the total economy in the euro area. Meanwhile, GDP is a more comprehensive measure and therefore more appropriate for analysis of fluctuations. Nevertheless, in some cases it is not crucial which of these indicators are used in the research because the cyclical fluctuations of both series have been very similar (ECB, 2001).
The researchers at the NBER in the US analyse the business cycles identifying the months of ups and downs in general economic activity taking into account the payroll employment, the real personal income excluding transfers, industrial production and the volume of sales of the manufacturing and wholesale-retail sectors. In general, significant drop of overall economic activity is inherent for a recession and it lasts for more than a few months, while it is long-lasting process in the case of recovery (Rua \& Nunes, 2005).

Rua and Nunes (2005) aimed to construct coincident and leading composite indicators which were able to provide early information about the current and future economic fluctuations in euro area, respectively. They research, based on the data of the euro area for the period 1987-2001, showed that the manufacturing and construction surveys provided the leading information at long cycles. The significance of different questions of consumer survey varied, but the questions about the households' financial situation and their expectations on general economic situation were the most important for economic fluctuations. In addition, the industrial production of intermediate goods was slightly leading at medium cycles and the industrial production of consumer goods revealed a lag at long cycles.

Qi (2001) examined the relevance of various economic and financial indicators (including stock price indexes, interest rates and spreads, individual macro indicators, monetary aggregates and composite leading indexes) in predicting the US recessions via neural network models. The results showed that the indicators, such as Department of Commerce leading index, S\&P500 index, Stock and Watson index as well as interest rate spread were useful in predicting the recessions in the US. Furthermore, they found that the importance of various leading indicators might change from time to time. The author suggests that researchers should be cautious when choosing the potential leading indicators in order to predict recession in a particular period even if the identical model is used (Qi, 2001).

Qin et al. (2008) compared the predictions made by macroeconometric structural models (MESMs) and performance of automatic leading indicators (ALIs) using data of Indonesia, the Philippines, and China and noticed that ALIs outperformed MESMs for one-period-ahead forecasts, but this advantage disappeared if the forecast horizon is longer. Various applications of the ALI method showed that it can outperform the traditional VAR models (Banerjee et al., 2003).

Qin et al. (2008) declare that the usage of higher frequency data does not always help to improve forecasts and recommends to analyse different frequency data and to compare the results. The use of monthly data, in comparison of quarterly data, can help to improve the precision of prediction, but it can also cause the undesirable noise. To avoid such a risk, the data features should be carefully considered. According to the researchers, both good economic sense and theory are necessary in choosing data.

Frankel \& Saravelos (2012) investigated if the leading indicators could help explain the financial crisis in 2008-09. They analysed data of various countries over the world and suspected that indicators that were useful predictors in one round of crises were not useful to predict the next round. The researchers found that past movements in the real 
exchange rate and central bank reserves were the most important leading indicators explaining the crisis incidence across various countries.

Rose and Spiegel (2011) also sought for simple quantitative models to explain the same crisis. They analysed different indicators and countries and found few reliable indicators. They concluded that countries where income are higher and credit market regulation is looser suffer from deeper crises and countries that have current account surpluses are better protected from slowdown.

In general, various studies show that the real exchange rate, foreign exchange reserves, the current account, GDP and the growth rate of credit are the most frequent statistically significant early warning indicators of the crisis in 2008. Lower past credit growth, external and short-term debt and larger current accounts and saving rates were associated with lower crisis incidence (Frankel \& Saravelos, 2012).

Laina et al. (2015) investigated the warning indicators of banking crises in $11 \mathrm{EU}$ countries using quarterly data from 1980Q1 to 2013Q2. They found that loans-to-deposits (contrary to previous studies) and house price growth were the best warning indicators. Growth rates and trend deviations of loan stock variables, i.e. mortgages, household loans and private loans, also gave useful information about crises. Indicators signalled about the changes in economics 1-4 years before and the optimal lead horizon is three years. This should be taken into consideration by policymakers when making the decision about the application of certain macroprudential tools. The researchers did not find that any macroeconomic variable except the real growth of GDP was significant leading indicator. Inflation, real interest rates and current account deficits were not significant leading indicators (Laina et al., 2015).

Furthermore, there is a group of research that analyse business cycle dynamics with duration dependence (Layton \& Smith, 2007; IIboshi, 2007; Castro, 2010). The researchers support an idea that the older is an expansion or contraction, the more likely it is to end. Their research indicates that duration is also an important and statistically significant determinant of the termination of recessions.

Christiansen (2013) considers severe simultaneous recessions analysing the yield spread. A severe simultaneous recession occurs when at least half of the countries under investigation are in recession simultaneously. The researcher analysed six developed countries, i.e. Australia, Canada, Germany, Japan, the UK and the US. According to the researcher, small yield spreads imply future simultaneous recessions. Yield spreads in Germany and the US are leading indicators for simultaneous recessions but German yield spreads provide more additional information for predicting future simultaneous recessions. The future simultaneous recessions can be better predicted for longer horizons. In many cases, the results regarding severe simultaneous recessions are similar to the results for single-country recessions (Christiansen, 2013).

In general, the forecasters are still not satisfied with the precision. The precision of macroeconomic forecasts in the G7 has not improved over the last fifty years. Some researchers criticize macroeconometric models, others blame unrealistic expectations of the users (Heilemann \& Stekler, 2007). Oller and Teterukovsky (2007) point out the problem of measuring the quality of macroeconomic data. Stekler (2007) adds that researchers should choose appropriate models and analyse the data more thoroughly in order to improve the forecasting accuracy. The key factor for further improvements in forecasting accuracy is an orientation to all aspects of the prediction process, but not on the one of them.

Carriero and Marcellino (2007) provided an overview of methodologies used for the calculation of composite leading and coincident indexes, and applied them to the UK. They found that factor based techniques were promising for building continuous composite coincident index, however, the results were similar to those obtained from a simple average of the standardized index components. They also conclude that the choice of the components of the index is very important, because the best leading indicators change over time. In addition, the procedures for forecasting the turning points should be upgraded, because many of the recently used methods do not provide satisfying results yet.

The European Central Bank (ECB, 2001) recognizes that composite indicators can be informative for the economic short-term analysis but also concludes that they cannot replace a comprehensive evaluation of the individual indicators. Usually composite indicators conceal the properties of individual indicators which provide relevant information and therefore a thorough analysis of individual variables is necessary for the detailed evaluation of changes in the economic activity.

The literature provides various early warning models (EWMs) that aim to identify the leading indicators. Despite significant progress on this subject, there is still ample room for researching indicators that warn about the changes in economy (Babecky et al., 2013).

\section{Methodology}

The literature analysis shows that identification of leading indicators is still on-going issue. Various studies find different importance of potential leading indicators. It tends to the conclusion that the leading indicators can vary among countries. That's why it is important to make the analysis on each country level. The purpose of this research is to identify the leading indicators of the economic cycles and herewith fluctuations of the whole economy of Lithuania. In general, they can be measured by GDP. Potential leading indicators are taken based on the literature analyses and can be joined into following groups:

- economic data: current account, current plus capital account (balance $=$ net lending $(+) /$ net borrowing $(-)$ ), general government deficit (net lending (+) /net borrowing $(-))$ as a percentage of GDP, government consolidated gross debt as a percentage of GDP, unemployment as a percentage of total population, unemployment as a percentage of active population, final consumption expenditure of households as a percentage of GDP, compensation of employees as a percentage of GDP, final consumption expenditure of households in current prices, compensation of employees in current prices;

- industry data: volume index of production in mining and quarrying, manufacturing, electricity, gas, steam and air conditioning supply, volume index of intermediate goods production, volume index of consumer goods production, 
turnover of wholesale and retail trade including repair of motor vehicles and motorcycles, turnover of wholesale trade, except of motor vehicles and motorcycles, turnover of retail trade, except of motor vehicles and motorcycles, deflated turnover of retail trade, except of motor vehicles and motorcycles, assessment of current production capacity, current level of capacity utilization, new orders in recent months, export expectations for the months ahead, average number of usual weekly hours of employed persons;

- real estate market data: residential buildings permits, percentage change in residential buildings permits (compared to the same period in previous year), growth rate in house price index (compared to the same quarter in previous year);

- financial data: short-term interest rate, long-term interest rate, yield spread, OMXV index (i.e. stock market index);

- consumer and business expectations: financial situation over the last 12 months, financial situation over the next 12 months, general economic situation over the last 12 months, general economic situation over the next 12 months, price trends over the last 12 months, price trends over the next 12 months, unemployment expectations over the next 12 months, the current economic situation is adequate to make major purchases, major purchases over the next 12 months, the current economic situation is adequate for savings, savings over the next 12 months, statement on financial situation of household, consumer confidence indicator, construction confidence indicator, industrial confidence indicator, retail confidence indicator, services confidence indicator.

The leading indicators will be found by application of Granger causality test. The Granger causality test lets determine whether one time series is useful for prediction of another one. It tests whether $x$ causes $y$, i.e. to what extent the current $y$ can be explained by the past values of $y$ and whether inclusion of lagged values of $x$ can improve the explanation.

The effect of twelve previous quarters (twelve lags of variables) will be examined. The following regressions will be tested:

$$
\begin{gathered}
y_{t}=\alpha_{0}+\alpha_{1} y_{t-1}+\alpha_{2} y_{t-2}+\cdots+\alpha_{12} y_{t-12}++\beta_{1} x_{t-1}+ \\
\beta_{2} x_{t-2}+\cdots+\beta_{12} x_{t-12}+\varepsilon_{t} \\
x_{t}=\alpha_{0}+\alpha_{1} x_{t-1}+\alpha_{2} x_{t-2}+\cdots+\alpha_{12} x_{t-12}++\beta_{1} y_{t-1}+ \\
\beta_{2} y_{t-2}+\cdots+\beta_{12} y_{t-12}+\varepsilon_{t} .
\end{gathered}
$$

Here $t$ denotes the time period, $y_{t-l}$ and $x_{t-l}$ are variables with lags $(l=0, \ldots, 12), \alpha_{l}$ and $\beta_{l}$ are parameters of the model, $\varepsilon_{t}$ is an error of the model. The following hypothesis is tested for each equation:

$$
H_{0}: \beta_{1}=\beta_{2}=\ldots=\beta_{12}=0 .
$$

The null hypothesis is that $x$ does not Granger-cause $y$ in the (1) regression and that $y$ does not Granger-cause $x$ in the (2) regression. $y$ is Granger-caused by $x$ if $x$ improves the prediction of $y$, or, in other words, if the coefficients on the lagged $x$ 's in the equation (1) are statistically significant.

Since the purpose of this research is to find the indicators that cause the changes in GDP, only (1) equation will be analysed, where $y$ is growth rate of GDP (compared to the same quarter of previous year) and $x$ is potential leading indicator. The following hypothesis will be tested: $\mathrm{H}_{0}$ : certain indicator does not Granger-cause the growth rate of GDP.
The null hypothesis is accepted if calculated probability is higher than the significant level that is set to 0.05 . Otherwise the null hypothesis is rejected and certain indicator Granger-causes the growth rate of GDP.

Lastly the relationship between indicators will be described by autoregressive distributed lag model (ADL). It will be created according to the results of Granger causality test. The best lag value of dependent variable will be chosen according to the Akaike (AIC) criterion (its minimum value). The general form of ADL model where the lag cannot be higher than 12 can be written as

$$
\begin{aligned}
& y_{t}=\alpha_{0}+\alpha_{1} y_{t-1}+\alpha_{2} y_{t-2}+\cdots+\alpha_{12} y_{t-12}+ \\
& +\beta_{0} x_{t}+\beta_{1} x_{t-1}+\beta_{2} x_{t-2}+\cdots+\beta_{12} x_{t-12}+\varepsilon_{t} .
\end{aligned}
$$

All the statistical data are taken from Eurostat and the OECD databases. The research covers the analysis of quarterly data between the first quarter of 1996 and the second quarter of 2016 (but some time series are shorter and starts from 2001). Calculations are made by econometric software Gretl.

\section{Results}

Potential leading indicators are analysed by their groups presented in methodology.

Economic data. The results of Granger causality test (probabilities) of the economic indicators are presented in Table 1. They show that the economic indicators that are analysed in this research can hardly be leading indicators. The growth rate of GDP for the quarter $t$ can be forecasted only by the unemployment as a percentage of active population and compensation of employees as a percentage of GDP of the previous quarter. As the statistical data are announced with a delay, one lag has little benefit, i.e. usually the information about the changes in economy one quarter before is too late.

Granger causality test also finds the significant cause of final consumption expenditure of households as a percentage of GDP on the growth rate of GDP when lag is eight. Mentioned economic indicators are taken into account in order to create autoregressive distributed lag model. Minimum value of Akaike criterion is got when the lag value of dependent variable is five. Significant ADL model is written below:

$$
\begin{gathered}
y_{t}=1.3288+1.1064 \cdot y_{t-1}-0.8317 \cdot y_{t-4}++0.5022 \\
y_{t-5}+0.3015 \cdot x_{1-1}-0.5151 \cdot x_{1-4}+ \\
+0.4201 \cdot x_{1-8}-0.3346 \cdot x_{2 t-1} .
\end{gathered}
$$

Here $y_{t}, y_{t-1}, y_{t-4}$ and $y_{t-5}$ are the growth rates of GDP in the current quarter, one quarter, four quarters and five quarters before; $x_{1 t-1}, x_{1-4}$ and $x_{1 t-8}$ are final consumption expenditure of households as a percentage of GDP one, four and eight quarters before; $x_{2} t_{t-1}$ is compensation of employees as a percentage of GDP of the previous quarter. In general final consumption expenditure of households has positive impact, while compensation of employees has negative impact on the growth rate of GDP.

All the parameters are significant at the significance level of 0.05 and adjusted R-squared of the model is equal to 0.8676 . Residuals are not autocorrelated (Durbin-Watson statistic $=2.1912, \mathrm{p}=0.6837)$. However they are not distributed by normal distribution $\left(\chi^{2}(2)=35.504, \mathrm{p}=\right.$ 0.0000) and heteroskedastic according to Breusch-Pagan test $(\mathrm{LM}=77.1385, \mathrm{p}=0.0000)$. 
Table 1

Probabilities of Granger Causality Test Considering the Economic Indicators

\begin{tabular}{|c|c|c|c|c|c|c|c|c|c|c|c|c|}
\hline Indicator & $l=1$ & $l=2$ & $l=3$ & $l=4$ & $l=5$ & $l=6$ & $l=7$ & $l=8$ & $l=9$ & $l=10$ & $l=11$ & $l=12$ \\
\hline $\begin{array}{l}\text { Unemployment, } \% \text { of } \\
\text { total population }\end{array}$ & 0.0745 & 0.2032 & 0.3729 & 0.1766 & 0.2674 & 0.4845 & 0.5573 & 0.5845 & 0.6085 & 0.5624 & 0.8490 & 0.9171 \\
\hline $\begin{array}{l}\text { Unemployment, \% of } \\
\text { active population }\end{array}$ & 0.0493 & 0.2082 & 0.3841 & 0.1289 & 0.1348 & 0.2401 & 0.2158 & 0.4093 & 0.2217 & 0.2709 & 0.6715 & 0.7792 \\
\hline $\begin{array}{ll}\begin{array}{l}\text { General } \\
\text { deficit }\end{array} & \text { government } \\
\end{array}$ & 0.9851 & 0.9162 & 0.7469 & 0.7006 & 0.9073 & 0.9384 & 0.9755 & 0.9936 & 0.9976 & 0.9967 & 0.9889 & 0.9962 \\
\hline $\begin{array}{l}\text { Government } \\
\text { consolidated gross debt }\end{array}$ & 3302 & 0.8165 & 0.9580 & 0.9650 & 0.9737 & 0.9858 & 0.9737 & 0.9747 & 0.9585 & 0.9583 & 0.9887 & 0.9885 \\
\hline Current account & 0.0564 & 0.3455 & 0.4852 & 0.4602 & 0.4447 & 0.5732 & 0.7322 & 0.7494 & 0.6686 & 0.6662 & 0.6947 & 0.8309 \\
\hline $\begin{array}{l}\text { Current plus capital } \\
\text { account }\end{array}$ & 0.1264 & 0.3762 & 0.6562 & 0.7944 & 0.7453 & 0.7907 & 0.8916 & 0.7979 & 0.7004 & 0.6367 & 0.6010 & 0.7294 \\
\hline $\begin{array}{l}\text { Final consumption } \\
\text { expenditure } \\
\text { households, \% GDP }\end{array}$ & 0.7644 & 0.2113 & 0.3100 & 0.3345 & 0.4913 & 0.6007 & 0.7343 & 0.0325 & 0.1068 & 0.1059 & 0.1260 & 0.0686 \\
\hline $\begin{array}{l}\text { Compensation } \\
\text { employees, \% GDP }\end{array}$ & 0.0187 & 0.0521 & 0.1811 & 0.3723 & 0.3713 & 0.5982 & 0.4046 & 0.5805 & 0.4393 & 0.5737 & 0.8195 & 0.8216 \\
\hline $\begin{array}{l}\text { Final consumption } \\
\text { expenditure of house- } \\
\text { holds in current prices }\end{array}$ & 0.1422 & 0.2307 & 0.4641 & 0.2908 & 0.6257 & 0.3408 & 0.4273 & 0.4596 & 0.6313 & 0.5941 & 0.4785 & 0.1334 \\
\hline $\begin{array}{l}\text { Compensation } \begin{array}{r}\text { of } \\
\text { employees in current } \\
\text { prices }\end{array}\end{array}$ & 0.0830 & 0.1348 & 0.3570 & 0.2170 & 0.4499 & 0.1734 & 0.2246 & 0.2692 & 0.0624 & 0.1123 & 0.1360 & 0.2502 \\
\hline
\end{tabular}

Industry data. The results of Granger-causality test considering the industry indicators are presented in Table 2. In general industry data are better predictors of the growth rate of GDP. Volume index of intermediate goods production is the best leading indicator in this group, i.e. it Granger-causes the growth rate of GDP when the lag is three and more. New orders in recent months and export expectations for the months ahead Granger-cause the growth rate of GDP when the lag varies from one to three, while average number of usual weekly hours Granger- causes the growth rate of GDP when the lag is one and two. These indicators can be called as late warning indicators. Assessment of current production capacity can be useful for prediction of the changes in economy when lag is five. Meanwhile turnover of wholesale and retail trade, repair of motor vehicles and motorcycles and turnover of retail trade, except of motor vehicles and motorcycles are good predictors when lag is seven and eight. Current level of capacity utilization is the earliest warning indicator which Grangercauses the growth of GDP when lag is ten and twelve.

Table 2

Probabilities of Granger Causality Test Considering the Industry Indicators

\begin{tabular}{|c|c|c|c|c|c|c|c|c|c|c|c|c|}
\hline Indicator & $l=1$ & $l=2$ & $l=3$ & $l=4$ & $l=5$ & $l=6$ & $l=7$ & $l=8$ & $l=9$ & $l=10$ & $l=11$ & $l=12$ \\
\hline $\begin{array}{l}\text { Assessment of current } \\
\text { production capacity }\end{array}$ & 0.4773 & 0.6200 & 0.4795 & 0.1584 & 0.0334 & 0.0687 & 0.1283 & 0.2299 & 0.3972 & 0.5296 & 0.4357 & 0.4502 \\
\hline $\begin{array}{l}\text { New orders in recent } \\
\text { months }\end{array}$ & 0.0006 & 0.0047 & 0.0066 & 0.0717 & 0.0740 & 0.1305 & 0.1357 & 0.2783 & 0.4386 & 0.5523 & 0.4705 & 0.6010 \\
\hline $\begin{array}{l}\text { Export expectations for } \\
\text { the months ahead }\end{array}$ & 0.0010 & 0.0086 & 0.0198 & 0.0888 & 0.2443 & 0.2586 & 0.4165 & 0.2906 & 0.2374 & 0.2152 & 0.2934 & 0.2800 \\
\hline $\begin{array}{l}\text { Current level of capacity } \\
\text { utilization }\end{array}$ & 0.4231 & 0.1278 & 0.1829 & 0.6711 & 0.7231 & 0.9071 & 0.2874 & 0.5242 & 0.0599 & 0.0245 & 0.1198 & 0.0384 \\
\hline $\begin{array}{l}\text { Average number of usual } \\
\text { weekly hours }\end{array}$ & 0.0175 & 0.0450 & 0.2228 & 0.1474 & 0.3053 & 0.6482 & 0.7354 & 0.7062 & 0.1603 & 0.1218 & 0.0520 & 0.0718 \\
\hline $\begin{array}{l}\text { Volume index of } \\
\text { production in mining, } \\
\text { quarrying, } \\
\text { manufacturing, } \\
\text { electricity, gas, steam and } \\
\text { air conditioning supply }\end{array}$ & 0.3363 & 0.5584 & 0.6024 & 0.6257 & 0.4458 & 0.4527 & 0.4034 & 0.2925 & 0.3206 & 0.4337 & 0.5165 & 0.2128 \\
\hline $\begin{array}{l}\text { Volume index of } \\
\text { intermediate goods } \\
\text { production }\end{array}$ & 0.8484 & 0.1365 & 0.0093 & 0.0008 & 0.0000 & 0.0000 & 0.0000 & 0.0000 & 0.0000 & 0.0000 & 0.0000 & 0.0000 \\
\hline $\begin{array}{l}\text { Volume index of } \\
\text { consumer goods } \\
\text { production }\end{array}$ & 0.4565 & 0.7009 & 0.6018 & 0.4326 & 0.3160 & 0.3950 & 0.3957 & 0.2048 & 0.1557 & 0.1992 & 0.0712 & 0.0874 \\
\hline $\begin{array}{l}\text { Turnover of wholesale } \\
\text { and retail trade, repair of } \\
\text { motor vehicles and } \\
\text { motorcycles }\end{array}$ & 0.2444 & 0.3941 & 0.4126 & 0.3518 & 0.5406 & 0.0535 & 0.0498 & 0.0357 & 0.0879 & 0.1349 & 0.1550 & 0.1931 \\
\hline $\begin{array}{l}\text { Turnover of wholesale } \\
\text { trade, except of motor } \\
\text { vehicles and motorcycles }\end{array}$ & 0.3086 & 0.5214 & 0.5574 & 0.5440 & 0.6492 & 0.2617 & 0.3046 & 0.2192 & 0.3369 & 0.4317 & 0.3721 & 0.3468 \\
\hline
\end{tabular}




\begin{tabular}{|l|c|c|c|c|c|c|c|c|c|c|c|c|}
\hline Indicator & $\mathbf{l}=\mathbf{1}$ & $\mathbf{l = 2}$ & $\mathbf{l}=\mathbf{3}$ & $\mathbf{l}=\mathbf{4}$ & $\mathbf{l = 5}$ & $\mathbf{l = 6}$ & $\mathbf{l = 7}$ & $\mathbf{l = 8}$ & $\mathbf{l = 9}$ & $\mathbf{l = 1 0}$ & $\mathbf{l = 1 1}$ & $\mathbf{l}=\mathbf{1 2}$ \\
\hline $\begin{array}{l}\text { Turnover of retail trade, } \\
\text { except of motor vehicles } \\
\text { and motorcycles }\end{array}$ & 0.1415 & 0.3001 & 0.3805 & 0.2895 & 0.4871 & 0.0613 & 0.0347 & 0.0409 & 0.1609 & 0.2399 & 0.1274 & 0.1732 \\
\hline $\begin{array}{l}\text { Deflated turnover of } \\
\text { retail trade, except of } \\
\text { motor vehicles and } \\
\text { motorcycles }\end{array}$ & 0.1243 & 0.3448 & 0.4528 & 0.3804 & 0.4506 & 0.5575 & 0.4656 & 0.4923 & 0.6258 & 0.5838 & 0.5626 & 0.4848 \\
\hline
\end{tabular}

All these indicators are put into ADL model, but most of them become insignificant and are thrown from the model. The best significant ADL model is written below:

$$
\begin{aligned}
& y_{t}=4.6104+0.5569 \cdot y_{t-1}-0.4954 \cdot y_{t-4}+ \\
& +0.3642 \cdot y_{t-5}+0.1812 \cdot x_{1 t-1}+0.0838 \cdot x_{1-4}-(5) \\
& \quad-0.1843 \cdot x_{1-5}-0.1215 \cdot x_{1 t-8} .
\end{aligned}
$$

Here $y_{t}, y_{t-1}, y_{t-4}$ and $y_{t-5}$ are the growth rates of GDP at the current quarter, one quarter, four quarters and five quarters before; $x_{1 t-1}, x_{1 t-4}, x_{1 t-5}$ and $x_{1 t-8}$ are volume indices of intermediate goods production one, four, five and eight quarters before. The results show that production of intermediate goods of the last year (four quarters) has positive impact on the growth rate of GDP, but its earlier values (five and eight quarters before) have stopping effect on the growth rate of GDP.

All the parameters are significant at the significance level of 0.05 and adjusted R-squared of the model is equal to 0.9215 . Residuals are not autocorrelated (Durbin-Watson statistic $=2.1555, \mathrm{p}=0.5730)$. However they are not distributed by normal distribution $\left(\chi^{2}(2)=7.282, \mathrm{p}=\right.$ $0.0262)$ and heteroskedastic according to Breusch-Pagan test $(\mathrm{LM}=29.0928, \mathrm{p}=0.0001)$.

Real estate market data. The results of Granger causality test considering the real estate market indicators are presented in Table 3. The results show that residential buildings permits and growth rate in house price index can be the predictors of the growth rate of GDP.

Table 3

Probabilities of Granger Causality Test Considering the Real Estate Market Indicators

\begin{tabular}{|l|c|c|c|c|c|c|c|c|c|c|c|c|}
\hline Indicator & $\boldsymbol{l = 1}$ & $\boldsymbol{l = 2}$ & $\boldsymbol{l = 3}$ & $\boldsymbol{l = 4}$ & $\boldsymbol{l = 5}$ & $\boldsymbol{l = 6}$ & $\boldsymbol{l = 7}$ & $\boldsymbol{l = 8}$ & $\boldsymbol{l = 9}$ & $\boldsymbol{l = 1 0}$ & $\boldsymbol{l = 1 1}$ & $\boldsymbol{l = 1 2}$ \\
\hline $\begin{array}{l}\text { Residential buildings } \\
\text { permits }\end{array}$ & 0.2677 & 0.2659 & 0.1503 & 0.2332 & 0.0105 & 0.0129 & 0.0316 & 0.0545 & 0.0773 & 0.0549 & 0.1409 & 0.2492 \\
\hline $\begin{array}{l}\text { Percentage change in } \\
\text { residential buildings } \\
\text { permits }\end{array}$ & 0.0810 & 0.1198 & 0.1564 & 0.1578 & 0.3194 & 0.4766 & 0.4865 & 0.3843 & 0.6905 & 0.5631 & 0.5978 & 0.1748 \\
\hline $\begin{array}{l}\text { Growth rate in house } \\
\text { price index }\end{array}$ & 0.2961 & 0.0147 & 0.1075 & 0.3313 & 0.0916 & 0.0214 & 0.0205 & 0.0431 & 0.3074 & 0.3632 & 0.3903 & - \\
\hline
\end{tabular}

The best significant ADL model is written below:

$$
\begin{aligned}
& y_{t}=7.2208-0.0431 \cdot x_{1 t-5}+0.3856 \cdot x_{2 t-1}- \\
& -0.4220 \cdot x_{2 t-4}+0.2960 \cdot x_{2 t-5}-0.0964 \cdot x_{2 t-8} .
\end{aligned}
$$

Here $x_{1-5}$ is residential buildings permits five quarters before; $x_{2 t-1}, x_{2 t-4}, x_{2 t-5}$ and $x_{2 t-8}$ are the growth rates in house price index one, four, five and eight quarters before. The residential buildings permits five quarters before have negative impact on the growth rate of GDP, while the impact of the growth rates in house price index is cyclical.
All the parameters are significant at the significance level of 0.05 and adjusted R-squared of the model is equal to 0.9076 . Residuals are distributed by normal distribution $\left(\chi^{2}(2)=2.020, p=0.3643\right)$, homoscedastic $(\mathrm{LM}=3.0750$, $\mathrm{p}=0.6884$ ) and not autocorrelated (Durbin-Watson statistic $=1.8923, \mathrm{p}=0.1603)$.

Financial data. The results of Granger-causality test of financial indicators are presented in Table 4 and they show

\begin{tabular}{|c|c|c|c|c|c|c|c|c|c|c|c|c|}
\hline Indicator & $l=1$ & $l=2$ & $l=3$ & $l=4$ & $l=5$ & $l=6$ & $l=7$ & $l=8$ & $l=9$ & $l=10$ & $l=11$ & $l=12$ \\
\hline Short-term interest rate & 0.5593 & 0.8917 & 0.9650 & 0.9598 & 0.4027 & 0.0193 & 0.0123 & 0.0360 & 0.0234 & 0.0106 & 0.0234 & 0.0333 \\
\hline Long-term interest rate & 0.9791 & 0.0159 & 0.0579 & 0.0455 & 0.1431 & 0.0989 & 0.0904 & 0.1714 & 0.3116 & 0.3606 & 0.2945 & 0.1924 \\
\hline Yield spread & 0.0022 & 0.0202 & 0.0882 & 0.2815 & 0.0994 & 0.1826 & 0.1140 & 0.2350 & 0.0956 & 0.0558 & 0.1472 & 0.1395 \\
\hline OMXV value & 0.7522 & 0.0173 & 0.0009 & 0.0001 & 0.0009 & 0.0026 & 0.0071 & 0.0008 & 0.0039 & 0.0012 & 0.0127 & 0.0004 \\
\hline
\end{tabular}
that all these indicators can be as the predictors of the growth rate of GDP using different lags.

Table 4

Probabilities of Granger Causality Test Considering the Financial Indicators

The best significant ADL model is written below:

$$
\begin{gathered}
y_{t}=-3.8916+0.9356 \cdot y_{t-1}-0.5334 \cdot y_{t-4}+ \\
+0.5584 \cdot y_{t-5}-1.9805 \cdot x_{1 t-1}+1.4401 \cdot x_{1 t-2}+ \\
+1.9871 \cdot x_{1-9}-1.1519 \cdot x_{1-10}+0.0248 \cdot x_{2 t-1}- \\
-0.0139 \cdot x_{2 t-2}-0.0147 \cdot x_{2 t-9}+0.0224 \cdot x_{2 t-10}- \\
-0.0130 \cdot x_{2 t-12} .
\end{gathered}
$$

Here $x_{1-i}(i=1,2,9$ and 10) are short-term interest rates $i$ quarters before; $x_{2}$ t-i $(i=1,2,9,10$ and 12) are OMXV values $i$ quarters before. Both indicators have not unified effect on the growth rate of GDP.

All the parameters are significant at the significance level of 0.05 and adjusted R-squared of the model is equal to 0.9376 . Residuals are distributed by normal distribution $\left(\chi^{2}(2)=0.856, p=0.6520\right)$, homoscedastic $(\mathrm{LM}=9.6873$, $\mathrm{p}=0.6434$ ) and not autocorrelated (Durbin-Watson statistic $=2.0707, \mathrm{p}=0.2276$ ). 
Consumer and business expectations. The results of Granger causality test considering the consumer and business expectations are presented in Table 5. All these indicators except price trends over the next 12 months, the current economic situation is adequate to make major purchases and the current economic situation is adequate for savings can also be the predictors of the growth rate of GDP.

Probabilities of Granger Causality Test Considering the Consumer and Business Expectations

\begin{tabular}{|c|c|c|c|c|c|c|c|c|c|c|c|c|}
\hline Indicator & $l=1$ & $l=2$ & $l=3$ & $l=4$ & $l=5$ & $l=6$ & $l=7$ & $l=8$ & $l=9$ & $l=10$ & $l=11$ & $l=12$ \\
\hline $\begin{array}{l}\text { Financial situation over } \\
\text { the last } 12 \text { months }\end{array}$ & 0.2736 & 0.5599 & 0.3568 & 0.0105 & 0.0188 & 0.0188 & 0.0193 & 0.0383 & 0.0482 & 0.0458 & 0.0309 & 0.0133 \\
\hline $\begin{array}{l}\text { Financial situation over } \\
\text { the next } 12 \text { months }\end{array}$ & 0.0445 & 0.0365 & 0.0256 & 0.0003 & 0.0000 & 0.0001 & 0.0002 & 0.0008 & 0.0023 & 0.0028 & 0.0081 & 0.0035 \\
\hline $\begin{array}{l}\text { General economic } \\
\text { situation over the last } \\
12 \text { months }\end{array}$ & 0.7254 & 0.0322 & 0.0192 & 0.0140 & 0.0356 & 0.0341 & 0.0516 & 0.0901 & 0.0487 & 0.0258 & 0.0461 & 0.0794 \\
\hline $\begin{array}{l}\text { General economic } \\
\text { situation over the next } \\
12 \text { months }\end{array}$ & 0.0005 & 0.0019 & 0.0014 & 0.0000 & 0.0001 & 0.0004 & 0.0009 & 0.0022 & 0.0053 & 0.0091 & 0.0307 & 0.0644 \\
\hline $\begin{array}{l}\text { Price trends over the } \\
\text { last } 12 \text { months }\end{array}$ & 0.0309 & 0.0305 & 0.0811 & 0.0781 & 0.3381 & 0.3277 & 0.4090 & 0.5744 & 0.6516 & 0.8020 & 0.8707 & 0.7454 \\
\hline $\begin{array}{l}\text { Price trends over the } \\
\text { next } 12 \text { months }\end{array}$ & 0.4434 & 0.4346 & 0.2657 & 0.3767 & 0.3159 & 0.0768 & 0.0543 & 0.1697 & 0.3217 & 0.3837 & 0.6241 & 0.6603 \\
\hline $\begin{array}{l}\text { Unemployment } \\
\text { expectations over the } \\
\text { next } 12 \text { months }\end{array}$ & 0.1095 & 0.0013 & 0.0006 & 0.0000 & 0.0000 & 0.0000 & 0.0000 & 0.0000 & 0.0000 & 0.0000 & 0.0000 & 0.0000 \\
\hline $\begin{array}{l}\text { The current economic } \\
\text { situation is adequate to } \\
\text { make major purchases }\end{array}$ & 0.8012 & 0.7427 & 0.7600 & 0.2945 & 0.2909 & 0.1381 & 0.1037 & 0.1265 & 0.2967 & 0.4164 & 0.3073 & 0.2803 \\
\hline $\begin{array}{l}\text { Major purchases over } \\
\text { the next } 12 \text { months }\end{array}$ & 0.0270 & 0.0256 & 0.0243 & 0.2844 & 0.0415 & 0.0362 & 0.0720 & 0.0419 & 0.0206 & 0.0019 & 0.0103 & 0.0141 \\
\hline $\begin{array}{l}\text { The current economic } \\
\text { situation is adequate for } \\
\text { savings }\end{array}$ & 0.5490 & 0.5919 & 0.8733 & 0.6236 & 0.5442 & 0.1509 & 0.1601 & 0.1978 & 0.1898 & 0.1461 & 0.0558 & 0.0539 \\
\hline $\begin{array}{l}\text { Savings over the next } \\
12 \text { months }\end{array}$ & 0.6397 & 0.8287 & 0.8332 & 0.2715 & 0.0428 & 0.0382 & 0.0292 & 0.0340 & 0.0301 & 0.0338 & 0.0790 & 0.0852 \\
\hline $\begin{array}{l}\text { Statement on financial } \\
\text { situation of household }\end{array}$ & 0.8000 & 0.8520 & 0.9375 & 0.4328 & 0.3924 & 0.2854 & 0.2070 & 0.0140 & 0.0143 & 0.0163 & 0.0300 & 0.0028 \\
\hline $\begin{array}{l}\text { Consumer confidence } \\
\text { indicator }\end{array}$ & 0.0551 & 0.0170 & 0.0110 & 0.0001 & 0.0000 & 0.0000 & 0.0001 & 0.0003 & 0.0009 & 0.0009 & 0.0044 & 0.0090 \\
\hline $\begin{array}{l}\text { Construction } \\
\text { confidence indicator }\end{array}$ & 0.8091 & 0.3945 & 0.6918 & 0.0542 & 0.0616 & 0.0717 & 0.0392 & 0.0986 & 0.0810 & 0.0856 & 0.0714 & 0.1003 \\
\hline $\begin{array}{l}\text { Industrial confidence } \\
\text { indicator }\end{array}$ & 0.0405 & 0.1020 & 0.1464 & 0.2817 & 0.0570 & 0.1247 & 0.1859 & 0.1162 & 0.0894 & 0.1198 & 0.1694 & 0.1598 \\
\hline $\begin{array}{l}\text { Retail confidence } \\
\text { indicator }\end{array}$ & 0.2753 & 0.0460 & 0.1109 & 0.0045 & 0.0024 & 0.0067 & 0.0110 & 0.0136 & 0.0051 & 0.0075 & 0.0285 & 0.0190 \\
\hline $\begin{array}{l}\text { Services confidence } \\
\text { indicator }\end{array}$ & 0.0000 & 0.0000 & 0.0002 & 0.0002 & 0.0001 & 0.0001 & 0.0003 & 0.0002 & 0.0031 & 0.0027 & 0.0022 & 0.0087 \\
\hline
\end{tabular}

Lots of significant models can be created using all or some of these indicators. In this case stepwise regression is conducted in order to find the model with the highest precision. The best significant ADL model is written below:

$$
\begin{gathered}
y_{t}=-4.282+0.141 \cdot x_{1 t-2}-0.047 \cdot x_{2 t-9}+ \\
+0.075 \cdot x_{2 t-11}-0.042 \cdot x_{3 t-5}-0.220 \cdot x_{4 t-8}+ \\
+0.172 \cdot x_{5 t-5}+0.189 \cdot x_{5 t-6}-0.44 \cdot x_{5 t-11}+ \\
+0.194 \cdot x_{6 t-1}-0.091 \cdot x_{6 t-5} .
\end{gathered}
$$

Here $x_{1 t-2}$ is financial situation over the last 12 months two quarters before; $x_{2} t-i$ ( $i=9$ and 11$)$ is general economic situation over the last 12 months $i$ quarters before; $x_{3 t-5}$ is general economic situation over the next 12 months 5 quarters before; $x_{4-8}$ is savings over the next 12 months 8 quarters before; $x_{5 t-i}(i=5,6$ and 11$)$ is statement on financial situation of household $i$ quarters before; $x_{6 t-i}(i=1$ and 5$)$ is services confidence indicator $i$ quarters before. All these indicators have different effect on the growth rate of GDP. Moreover, the effect also depends on time period.

All the parameters of the model are significant at the significance level of 0.05 and adjusted R-squared is equal to 0.975 . However, residuals are not distributed by normal distribution $\left(\chi^{2}(2)=7.146, \mathrm{p}=0.0281\right)$, are heteroskedastic $(\mathrm{LM}=29.2196, \mathrm{p}=0.0011)$, but not autocorrelated (DurbinWatson statistic $=1.8488, \mathrm{p}=0.0776$ ).

Finally all analysed indicators that Granger-cause the growth rate of GDP can be included into one model. The best ADL model in this case is

$$
\begin{gathered}
y_{t}=-31.7290+0.0421 \cdot x_{1 t-2}-0.0731 \cdot x_{2 t-2}--0.0760 \\
x_{3 t-4}-0.3804 \cdot x_{4 t-6}+0.5909 \cdot x_{5 t-6}- \\
-0.5424 \cdot x_{5 t-11} .
\end{gathered}
$$

Here $x_{1-2}$ is OMXV value two quarters before; $x_{2 t-2}$ is general economic situation over the last 12 months two quarters before; $x_{3 t-4}$ is growth rate in house price index four quarters before; $x_{4}$ t- 6 is savings over the next 12 months six quarters before; $x_{5 t-i}(i=6$ and 11) is statement on financial situation of household $i$ quarters before.

All the parameters of the model are significant at the significance level of 0.05 and adjusted R-squared is equal to 0.940 . Residuals are distributed by normal distribution $\left(\chi^{2}(2)=5.8536, p=0.0536\right)$ and not autocorrelated (DurbinWatson statistic $=2.5023, \mathrm{p}=0.7561)$. Breusch-Pagan test shows heteroscedasticity $(\mathrm{LM}=14.6048, \mathrm{p}=0.0236)$, but 
White's test indicate that residuals are homoscedastic (test statistic $=29.1616, \mathrm{p}=0.3038$ ).

The results tend to the conclusion that optimism in stock market shows the rise of economy in the near future. However, increase in consumer expectations on general economic situation over the last 12 months and savings over the next 12 months, as well as growth rate in house price index disclose the future decline in growth rate of GDP. Meanwhile, the impact of statement on financial situation of household on the growth rate of GDP depends on lag.

\section{Conclusions}

The success of the reaction to the business cycles or economic fluctuations mainly depends on the recognition of the changes in the leading indicators. The identification of the leading indicators is still under investigation all over the world. Various methods have been applied in order to find the warning indicators and predict the economic cycles. Despite that, still consensus is not reached as well as none of the existing models are reliable. The literature analysis tends to the conclusion that leading indicators can vary among countries and therefore it is important to make the analysis on each country level.

This research is based on Lithuanian data. Various economic, industrial, financial, real estate market indicators and consumer and business expectations were analysed in order to find the best leading indicators among them. The selection of the indicators that cause the changes in growth rate of GDP was justified by Granger causality test. The analysis shows that considered economic indicators are weak predictors of the growth rate of GDP. Volume index of intermediate goods production is the best predictor in the group of industry data as it holds predictive attributes even three years before the changes in economy. That can be also said about two financial indicators, i.e. short-term interest rate and the value of stock market index. Real estate market data such as residential buildings permits and growth rate in house price index can also show the changes in the growth rate of GDP two years before. Nevertheless, consumer and business expectations are the most important for prediction of the changes in growth rate of GDP.

All indicators that Granger-cause the growth rate of GDP were treated as potential independent variables in autoregressive distributed lag model. The final significant ADL model reveals that optimism in stock market shows the rise of economy after half a year. However, increase in consumer expectations on general economic situation over the last 12 months and savings over the next 12 months, as well as growth rate in house price index disclose the future decline in growth rate of GDP. Improvement in statement on financial situation of household has positive impact on the growth rate of GDP after six quarters, but negative impact after eleven quarters. This confirms that the growth as well as decline of any indicator cannot last forever and cycles in the economy are unavoidable.

The results of this research are similar to those got by Rua and Nunes (2005) based on the data of euro area for the period 1987-2001. They revealed that significance of consumer survey varies across the different questions, but those related with the financial situation of households and general economic situation seem to be the most informative for fluctuations in the economy.

Identical research should be done for each country in order to get the more accurate predictions of the economic cycles in a certain country. Comparison of the most important leading indicators of close countries, such as Lithuania, Latvia and Estonia would allow to compare the results and to provide more information about the similarities and differences among the economies.

\section{References}

Alessi, L., \& Detken, C. (2011). Quasi real time early warning indicators for costly asset price boom/bust cycles: a role for global liquidity. European Journal of Political Economy, 27(3), 520-533. https://doi.org/10.1016/ j.ejpoleco.2011.01.003

Azevedo, J. V., \& Pereira, A. (2013). Approximating and forecasting macroeconomic signals in real-time. International Journal of Forecasting, 29, 479-492. https://doi.org/10.1016/j.ijforecast.2012.12.005

Babecky, J., Havranek, T., Mat, J., Rusnak, M., Smidkova, K., \& Vasicek, B. (2013). Leading indicators of crisis incidence: Evidence from developed countries. Journal of International Money and Finance, 35, 1-19. https://doi.org/10.1016/ j.jimonfin.2013.01.001

Banbura, M., Giannone, D., Modugno, M., \& Reichlin, L. (2013). Now-casting and the real-time data flow. In: Elliott, G., Timmermann, A. (Eds.). Handbook of Economic Forecasting (Vol. 2a., pp. 195-237). North Holland, Amsterdam. https://doi.org/10.1016/b978-0-444-53683-9.00004-9

Banerjee, A., Marcellino, M., \& Masten, I. (2003). Leading indicators for Euro - area inflation and GDP growth. IGIER Working Papers, 235: Bocconi University.

Beber, A., Brandt, M.W., \& Luisi, M. (2015). Distilling the macroeconomic news flow. Journal of Financial Economics, 117, 489-507. https://doi.org/10.1016/j.jfineco.2015.05.005

Caldara, D., Fuentes-Albero, C., Gilchrist, S., \& Zakrajsek, E. (2016). The macroeconomic impact of financial and uncertainty shocks. European Economic Review. https://doi.org/10.1016/j.euroecorev.2016.02.020 
Carriero, A., \& Marcellino, M. (2007). A comparison of methods for the construction of composite coincident and leading indexes for the UK. International Journal of Forecasting, 23, 219-236. https://doi.org/10.1016/j.ijfo recast.2007.01.005

Castro, V. (2010). The duration of economic expansions and recessions: More than duration dependence. Journal of Macroeconomics, 32(1), 347-365. https://doi.org/10.1016/j.jmacro.2009.06.006

Christiansen, C. (2013). Predicting severe simultaneous recessions using yield spreads as leading indicators. Journal of International Money and Finance, 32, 1032-1043. https://doi.org/10.1016/j.jimonfin.2012.08.005

Conference Board (2001). Business Cycle Indicators Handbook.

ECB (2001, November). The information content of composite indicators of the euro area business cycle. European Central Bank Monthly Bulletin, 39-50.

Frankel, J., \& Saravelos, G. (2012). Can leading indicators assess country vulnerability? Evidence from the 2008-09 global financial crisis. Journal of International Economics, 87, 216-231. https://doi.org/10.1016/j.jinteco.2011.12.009

Heilemann, U., \& Stekler, H. (2007). Introduction to "The future of macroeconomic forecasting". International Journal of Forecasting, 23, 159-165. https://doi.org/10.1016/j.ijforecast.2007.01.001

IIboshi, H. (2007). Duration dependence of the business cycle in Japan: A Bayesian analysis of extended Markov switching model. Japan and the World Economy, 19(1), 86-111. https://doi.org/10.1016/j.japwor.2005.05.004

Koenig, E., Dolmas, S., \& Piger, J. (2003). The use and abuse of real-time data in economic forecasting. Review of Economics and Statistics, 85, 618-628. https://doi.org/10.1162/003465303322369768

Laina, P., Nyholm, J., \& Sarlin, P. (2015). Leading indicators of systemic banking crises: Finland in a panel of EU countries. Review of Financial Economics, 24, 18-35. https://doi.org/10.1016/j.rfe.2014.12.002

Larionova, N., \& Varlamova, J. (2014). Correlation analysis of macroeconomic and banking system Indicators. International Conference on Applied Economics (ICOAE) 2014. Procedia Economics and Finance, 14, $359-366$. https://doi.org/10.1016/S2212-5671(14)00724-2

Layton, A. P., \& Smith, D. R. (2007). Business cycle dynamics with duration dependence and leading indicators. Journal of Macroeconomics, 29(4), 855-875. https://doi.org/10.1016/j.jmacro.2006.02.003

Levanon, G., Manini, J.C., Ozyildirim, A., Schaitkin, B., \& Tanchua, J. (2015). Using financial indicators to predict turning points in the business cycle: The case of the leading economic index for the United States. International Journal of Forecasting, 31, 426-445. https://doi.org/10.1016/j.ijforecast.2014.11.004

Megna, R., \& Xu, Q. (2003). Forecasting the New York State economy: The coincident and leading indicators approach. International Journal of Forecasting, 19, 701-713. https://doi.org/10.1016/S0169-2070(03)00002-5

Nakaota, H., \& Fukuta, Y. (2013). The leading indicator property of the term spread and the monetary policy factors in Japan. Japan and the World Economy, 28, 85-98. https://doi.org/10.1016/j.japwor.2013.08.001

Oller, L. E., \& Teterukovsky, A. (2007). Quantifying the quality of macroeconomic variables. International Journal of Forecasting, 23, 205-217. https://doi.org/10.1016/j.ijforecast.2007.01.006

Qi, M. (2001). Predicting US recessions with leading indicators via neural network models. International Journal of Forecasting, 17, 383-401. https://doi.org/10.1016/S0169-2070(01)00092-9

Qin, D., Cagas, M. A., Ducanes, G., Magtibay-Ramos, N., \& Quising, P. (2008). Automatic leading indicators versus macroeconometric structural models: A comparison of inflation and GDP growth forecasting. International Journal of Forecasting, 24, 399-413. https://doi.org/10.1016/j.ijforecast.2008.04.002

Rose, A., \& Spiegel, M. (2011). Cross-country Causes and Consequences of the Crisis: An Update. Special Issue: Advances in International Macroeconomics: Lessons from the Crisis. European Economic Review, 55(3), $309-324$. https://doi.org/10.1016/j.euroecorev.2010.12.006

Rua, A., \& Nunes, L. C. (2005). Coincident and leading indicators for the euro area: A frequency band approach. International Journal of Forecasting, 21, 503-523. https://doi.org/10.1016/j.ijforecast.2005.02.001

Stekler, H. O. (2007). The future of macroeconomic forecasting: understanding the forecasting process. International Journal of Forecasting, 23, 237-248. https://doi.org/10.1016/j.ijforecast.2007.01.002

The article has been reviewed.

Received in November, 2016; accepted in June, 2017. 